\title{
Expansi Pasar Menggunakan Digital Marketing Untuk Para Pelaku UMKM Makanan Khas Maninjau
}

\author{
Nila Pratiwi ${ }^{1}$, Tonny Yuwanda ${ }^{1}$, Ullya Rahmi Aswin ${ }^{1}$, Danny Hidayat ${ }^{2}$ \\ ${ }^{1}$ Universitas Putra Indonesia "YPTK" Padang, Indonesia \\ ${ }^{2}$ Universitas Andalas, Indonesia \\ tonnyyuwanda@upiyptk.ac.id*
}

\begin{abstract}
The impact of the COVID-19 pandemic has touched the entire community, especially UMKM. It is time for businesses and affected communities to need to streamline technologies such as buying and selling platforms and social media to survive this pandemic. The purpose of this service is to foster the minds of businesses and the public to use digital marketing in order to expand market reach. This service method is carried out in a webinar by conducting pre-survey before the webinar and post-survey after the webinar, the analysis used is descriptive analysis. The webinar was carried out with 52 participants consisting of $43.1 \%$ of business operators and 59,6\% of the community residing in the Lake Maninjau area. The pre-survey results showed that the TCR value for the use of digital marketing which was $37.2 \%$ was classified as less and the TCR value for the interest in using digital marketing which was $52.2 \%$ classified as sufficient. After conducting the webinar, a post-survey was conducted again with the results that TCR for understanding webinar material was $65.2 \%$ classified as good, TCR for the interest in using digital marketing increased to $77.2 \%$ classified as good, TCR for digital marketing effectiveness in expanding the market ie $78 \%$ is classified as good and $88 \%$ of respondents think that digital marketing will help UMKM sales in this pandemic. Based on the results of the service, respondents felt a significant benefit in terms of using digital marketing.

Keyword : Digital Marketing, Market Expansion, Maninjau
\end{abstract}

\begin{abstract}
ABSTRAK
Dampak pandemi COVID - 19 telah menyentuh seluruh kalangan masyarakat, terutama pelaku usaha UMKM. Sudah saatnya pelaku usaha dan masyarakat yang terdampak perlu mengefektifkan teknologi seperti platform jual beli dan media sosial untuk bertahan pada masa pandemi ini. Tujuan pengabdian ini yaitu menumbuhkembangkan pemikiran pelaku usaha dan masyarakat untuk menggunakan digital marketing agar dapat memperluas jangakauan pasar. Metode pengabdian ini yaitu dilaksanakan secara webinar dengan melalukan pra-survey sebelum webinar dan pasca-survey setelah webinar, analisis yang digunakan yaitu analisis deskriptif. Webinar terlaksana bersama 52 peserta yang terdiri dari 43,1\% pelaku usaha dan 59,6\% masyarakat yang berdomisili area danau Maninjau, Hasil pra-survey menunjukkan bahwa nilai TCR untuk penggunaan digital marketing yaitu 37,2\% tergolong kurang dan nilai TCR untuk ketertarikan menggunakan digital marketing yaitu 52,2\% tergolong cukup. Setelah melaksanakan webinar, dilakukan kembali pasca-survey dengan hasil yaitu TCR untuk kepemahaman materi webinar sebesar 65,2\%
\end{abstract}

How to cite:

Pratiwi, N., Yuwanda, T., Aswin, U. R., \& Hidayat, D. (2021). Expansi Pasar Menggunakan Digital Marketing untuk Para Pelaku UMKM Makanan Khas Maninjau. Jurnal Pengabdian Multidisiplin, 1(1). https://doi.org/10.51214/japamul.v1i1.78 
tergolong baik, TCR untuk ketertarikan penggunaan digital marketing meningkat menjadi 77,2\% tergolong baik, TCR untuk kefektifan digital marketing dalam memperluas pasar yaitu 78\% tergolong baik dan $88 \%$ responden berpendapat bahwa digital marketing akan membantu penjualan UMKM dimasa pandemi ini. Berdasarkan hasil pengabdian tersebut, responden merasakan manfaat yang signifikan dalam hal penggunaan digital marketing.

Kata Kunci: Digital Marketing, Expansi Pasar, Maninjau

\section{PENDAHULUAN}

Corona Virus Disease 2019 (COVID - 19) menjadi topik hangat diawal tahun 2020. Mulai dari meningkatnya angka PHK hingga memukul para pebisnis yang memaksa mereka untuk menutup usahanya terutama usaha kecil menengah. Sudah saatnya pelaku usaha terdampak memanfaatkan dan mengoptimalkan kemajuan teknologi untuk bertahan ditengah pandemi ini. Berwirausaha merupakan satu bidang yang memberikan kontribusi yang signifikan dalam memacu pertumbuhan ekonomi Indonesia (Kusmulyono \& Mulya, 2019). Hal ini dikarenakan daya serap Usaha Mikro Kecil Menengah (UMKM) terhadap tenaga kerja yang sangat besar dan dekat dengan rakyat kecil. Masalah utama yang dihadapi oleh UMKM adalah pemasaran (Affan \& Irawan, 2020; Selamat et al., 2020; Ulfah et al., 2020) Digital marketing seharusnya menjadi alat pemasaran untuk tumbuhnya UMKM yang ada di tengah masyarakat dengan pasar yang lebih terbuka. Dampak kemajuan teknologi ini, harus dapat diterima dan dijalankan dengan baik oleh pelaku usaha sebagai peluang. Untuk itu, pelaku usaha seharusnya memiliki pengetahuan dan kemampuan menggunakan internet dengan baik (Rakhamtulloh et al., 2019; Susanto et al., 2020).

Salah satu kunci keberhasilan menghadapi persaingan yang global tersebut adalah strategi pemasaran untuk dapat mencapai pasar yang diharapkan (Damarwulan et al., 2018). Dalam pemasaran bisnis, internet membawa dampak transformasional yang menciptakan paradigma baru dalam bisnis, berupa digital marketing (Sedayu \& Suseno, 2020). Digital Marketing adalah salah satu media pemasaran yang saat ini sedang banyak digunakan pelaku UMKM untuk medukung perkembangan usahanya. Dengan kemampuan web/internet yang bisa mengirimkan berbagai bentuk data seperti teks, grafik, gambar, suara, animasi, atau bahkan video, maka banyak kalangan bisnis yang memanfaatkan teknologi ini untuk mempromosikan usahanya.

Maninjau merupakan salah satu nagari yang berada di Kecamatan Tanjung Raya, Kabupaten Agam, Provinsi Sumatera Barat. Kawasan nagari Maninjau ialah daerah pedesaan dengan jumlah penduduk 3,080 jiwa. Sebaran pekerjaan masyarakat Maninjau dapat dilihat pada Figure 1 berikut :

\section{Figure 1. Sebaran Pekerjaan Masyarakat Maninjau (Sensus BPS, 2017)}

Lain-lain

Jasa Kemasyarakatan pemerintah dan perorangan

Hotel dan Rumah Makan

Perdagangan

Petani

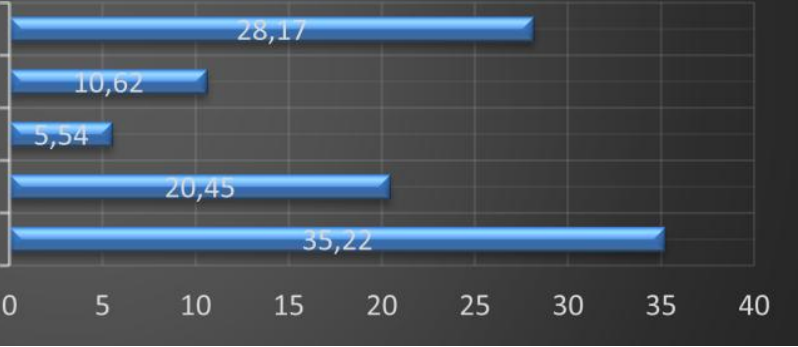



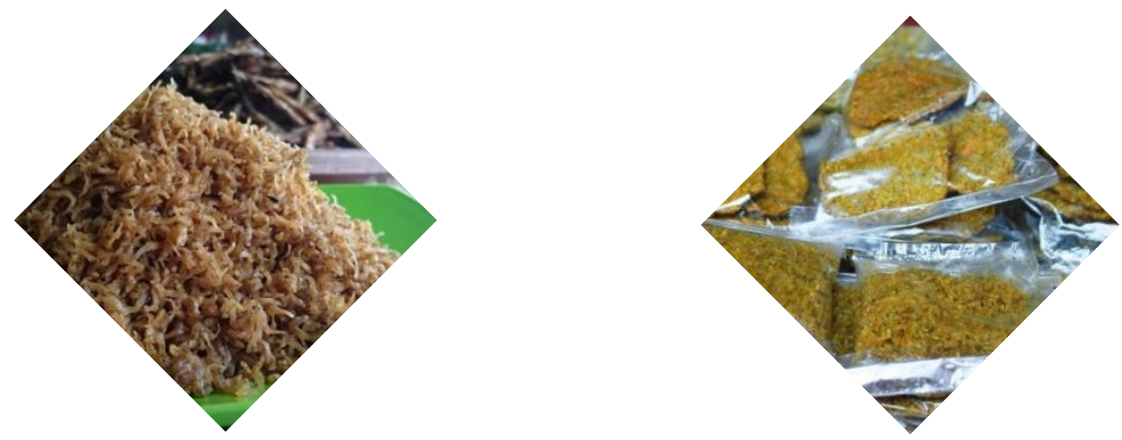

Berdasarkan Figure 1 dapat dijelaskan bahwasanya 20,45\% pekerjaan pada masyarakat Maninjau adalah berdagang, rata-rata perdagangan masyarakat di daerah Maninjau yaitu makanan khas kuliner ialah rinuak. Rinuak adalah ikan khas danau maninjau yang berbentuk seperti ikan teri nasi yang diolah menjadi makanan. Makanan khas ini banyak ditemui yang dijual oleh pedagang di sepanjang nagari Maninjau. Rinuak diolah oleh pedagang dan dijual cukup beragam seperti perkedel rinuak, peyek rinuak, palai rinuak dan aneka makanan khas lainnya. Strategi pemasaran yang digunakan layaknya pemasaran tradisional biasa, hal itu menjadikan tingginya tingkat persaingan antara pedagang makanan khas nagari ini.

Selain masyarakat nagari, konsumen utama wisata kuliner ini yaitu pendatang dari kota lain yang tengah berwisata ke danau Maninjau dengan arti kata lain makanan khas ini hanya dapat dijangkau dengan mendatangi nagari ini. Dengan tingginya tingkat persaingan dan keterbatasan tersebut maka perlu adanya perluasan pasar dengan menggunakan digital marketing agar makanan khas nagari ini dapat diminati dan dikonsumi oleh masyarakat luas. Penggunaan digital marketing menjadi sebuah kekuatan dalam tekhnik pemasaran dan setiap pedagang mempunyai potensi untuk menggunakannya (Busca \& Bertrandias, 2020). Trend digital marketing mendapat popularitas yang tinggi baik itu produk dan jasa (Kasilingam \& Thanuja, 2020). Upaya penggunaan digital marketing dapat dilakukan menggunakan media sosial yang terkemuka seperti Instagram, Facebook, Twitter, Youtube dan berbagai macam platform media sosial lainnya. Disisi lain platform jual beli juga tidak kalah penting seperti Tokopedia, Bukalapak, Shopee, OLX hingga forum jual beli seperti Kaskus dan blogspot buatan sendiri.

Alasan para pembeli menggunakan media online dalam bertransaksi yaitu dideterminasi oleh kemudahan prosedur pembelian, pembeli dapat membeli barang atau jasa tanpa harus mendatangi toko fisik serta dapat mengetahui keberagaman produk yang ditawarkan (Gajalakshmi, 2020). Hal ini menunjukkan bahwasanya dengan digital marketing para peminat makanan khas Maninjau dapat mudah membeli produk tanpa harus berkunjung dan mengetahui keanekaragaman olahan ikan khas Maninjau tersebut. Lebih jauh lagi, dengan tingkat capaian audiens relative tinggi pada media sosial menjadikan digital marketing turut serta mempromosikan wisata setempat (Fouskas et al., 2018; Makwana, 2020; Shrestha, 2019). Pengoptimalisasian digital marketing akan membantu memperluas jangkauan pasar serta membantu para pelaku UMKM setempat untuk tetap bertahan ditengah pandemi COVID - 19 ini.

Berdasarkan data pra-survey yang kami peroleh, bahwasanya 56,9\% responden di Maninjau mengatakan bahwa mereka belum pernah menggunakan digital marketing dan 54,9\% yang tidak mengetahui tujuan dan manfaat digital marketing. Hal ini menunjukkan bahwa rendahnya tingkat pengetahuan masyarakat dan pelaku usaha di sekitaran danau maninjau tentang digital marketing. Maka dari itu, peneliti ikut serta berkontribusi untuk mengedukasi masyarakat dan pelaku bisnis dalam pemanfaatan digital marketing. 


\section{METODE}

Target pada pengabdian masyarakat ini yaitu edukasi dalam hal digital marketing kepada para pelaku usaha dan masyarakat produktif di Maninjau pentingnya pengetahuan mereka dalam hal ini untuk dapat memajukan usaha mereka. Selain pengetahuan yang dimiliki, yang paling penting pengabdian masyarakat ini akan mampu memotivasi peserta untuk beralih dari promosi secara tradisional kepada promosi menggunakan digital marketing. Maka dari itu, populasi dan target peserta sosialisasi ini adalah pelaku usaha dan masyarakat produktif yang ada di Maninjau. Dalam Situasi pandemi COVID-19, maka sosialisasi dilaksanakan secara webinar dengan aplikasi Google Meet.

Metode pengumpulan data yaitu menyebarkan kuesioner (Pra Webinar) secara daring untuk mengukur tingkat kepemahaman peserta mengenai digital marketing sebelum webinar dan menyebarkan kuesioner kembali (Pasca Webinar) secara daring setelah webinar dilaksanakan. Pertanyaan yang diberikan kepada responden berskala likert dan alat analisis digunakan yaitu analisis deskriptif. Analisis deskriptif bertujuan untuk menggambarkan masing-masing pernyataan yang diteliti dengan cara menyajikan data ke dalam tabel distribusi frekuensi kemudian dilakukan analisis persentase (Sugiyono, 2016). Untuk melihat bagaimana capaian respon dari responden yaitu melihat TCR, dalam mencari Tingkat Capaian Responden (TCR) digunakan rumus:

$$
T C R=\frac{\bar{x}}{5} \times 100 \%
$$

Keterangan:

TCR =Tingkat ketercapaian responden

$\bar{x}=$ Skor rata-rata jawaban responden

5 = Jumlah alternatif jawaban

Riduwan (2012) mengemukakan krieteria jawaban responden sebagai berikut:
1. $0 \%-20 \%=$ sangat kurang
2. $21 \%-40 \%=$ kurang
3. $41 \%-60 \%=$ cukup
4. $61 \%-80 \%=$ baik
$5.81 \%-100 \%=$ sangat baik

Adapun jadwal pengabdian ini dapat dilihat pada figure 2 sebagai berikut:

Figure 2. Jadwal Pengabdian

\begin{tabular}{|c|c|c|c|c|c|c|c|c|c|c|c|c|c|c|c|c|c|c|c|c|c|c|c|c|}
\hline \multirow{3}{*}{ Kegiatan } & \multicolumn{24}{|c|}{ Tahun 2020} \\
\hline & \multicolumn{4}{|c|}{ Februari } & \multicolumn{4}{|c|}{ Maret } & \multicolumn{4}{|c|}{ April } & \multicolumn{4}{|c|}{ Mei } & \multicolumn{4}{|c|}{ Juni } & \multicolumn{4}{|c|}{ Juli } \\
\hline & 1 & 2 & 3 & 4 & 1 & 2 & 3 & 4 & 1 & 2 & 3 & 4 & 1 & 2 & 3 & 4 & 1 & 2 & 3 & 4 & 1 & 2 & 3 & 4 \\
\hline \multicolumn{25}{|l|}{ Persiapan } \\
\hline \multicolumn{25}{|l|}{ Screening } \\
\hline \multicolumn{25}{|l|}{ Impleme } \\
\hline \multicolumn{25}{|l|}{ ntasi } \\
\hline \multicolumn{25}{|l|}{ Evaluasi } \\
\hline \multicolumn{25}{|l|}{ Membuat } \\
\hline Lap. & & & & & & & & & & & & & & & & & & & & & & & & \\
\hline
\end{tabular}




\section{HASIL DAN PEMBAHASAN}

Setelah melakukan promosi webinar dan perizinan ke beberapa pihak terkait, akhirnya webinar terlaksana pada tanggal 07 Juni 2020 yang diikuti oleh 52 peserta.

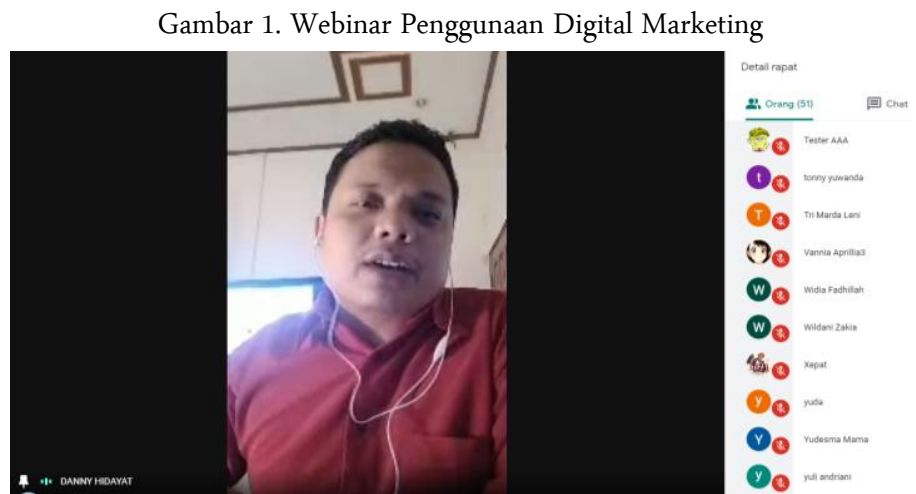

Adapun 52 peserta terdiri dari pelaku usaha UMKM dan masyarakat danau Maninjau. Materi dibawakan oleh Danny Hidayat, SE, MM selaku praktisi e-commerce dan dosen di Universitas Andalas. Suksesnya kegiatan ini juga dipublish pada media cetak Haluan Padang dan telah diseminarkan pada prosiding ADPI tanggal 16 Juli 2020.

Gambar 2. Publikasi Media Cetak Haluan Padang

\section{Digital Marketing Solusi UMKM di Tengah Pandemi}
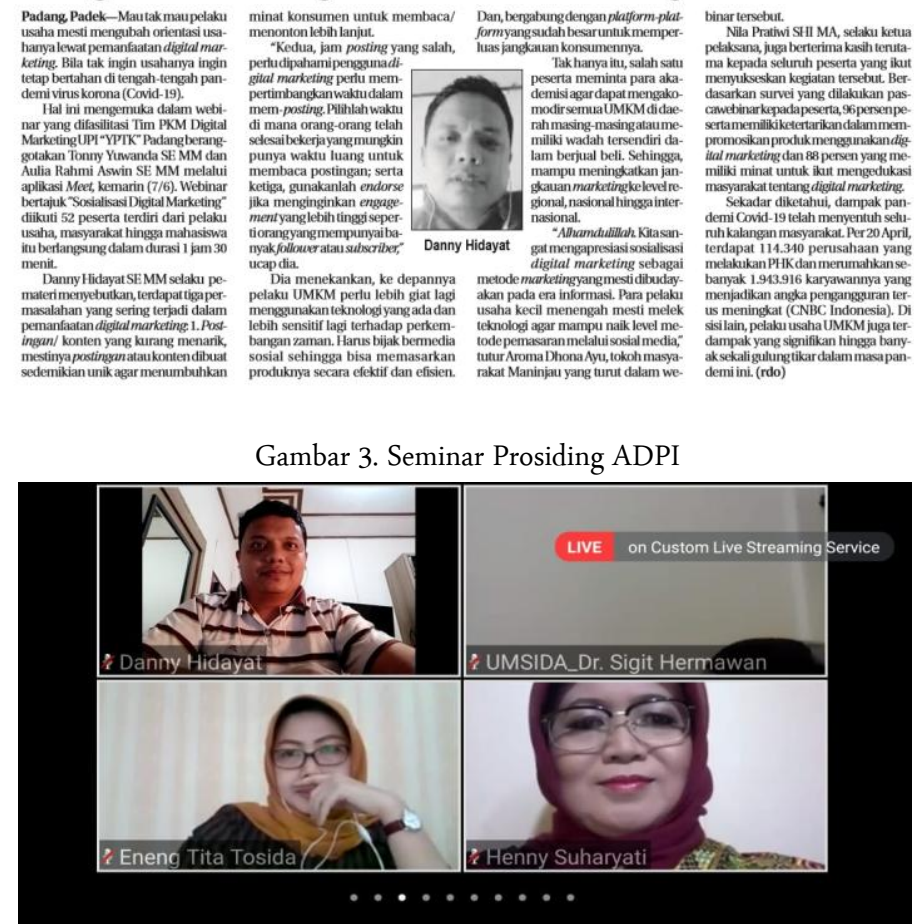

Berdasarkan proses pentabulasian data hasil penyebaran kuesioner maka dapat disajikan sebagai berikut: 


\section{A. Karakteristik Responden}

Pada tahap ini dilakukan analisa terhadap karakteristik responden berkaitan dengan responden sebagai yang dinyatakan pada bagian pertama dari kuesioner. Analisis dilakukan satu persatu berdasarkan pertanyaan dalam kuesioner dan pembahasan diawali dengan data perolehan dari responden.

\section{Jenis Kelamin}

Profil responden dibedakan berdasarkan jenis kelamin yang dapat dilihat pada Figure 3 dibawah ini:

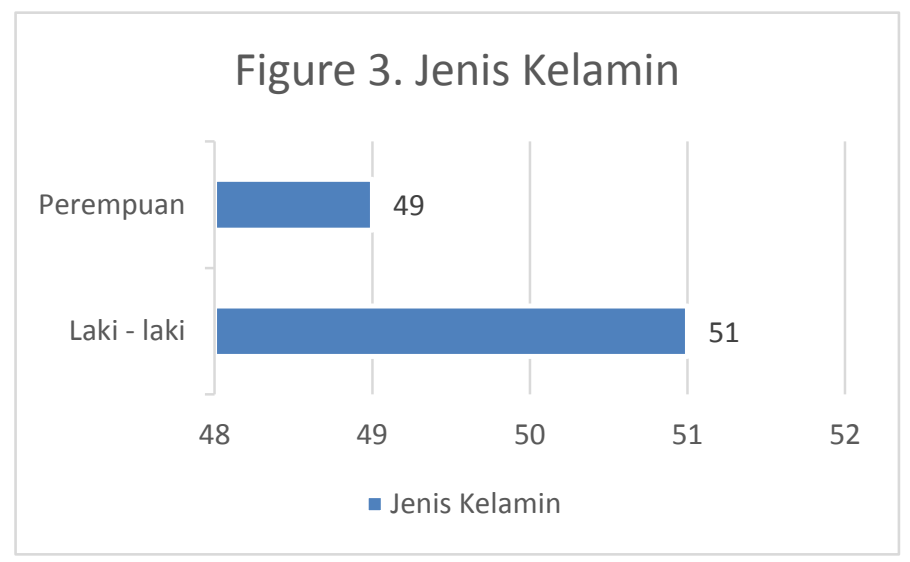

Dari Figure 3 dapat dilihat bahwa dari 51 orang responden, 26 orang (51\%) adalah laki-laki dan 25 (49\%) orang adalah perempuan dan ini memperlihatkan bahwa peserta yang mengikuti webinar lebih banyak laki-laki. Dengan demikian, dapat disimpulkan bahwa laki - laki lebih berminat mengikuti sosialisasi pemanfaatan digital marketing.

\section{Umur}

Profil responden berikutnya dibedakan berdasarkan umur yang dapat dilihat pada Figure 4 dibawah ini:

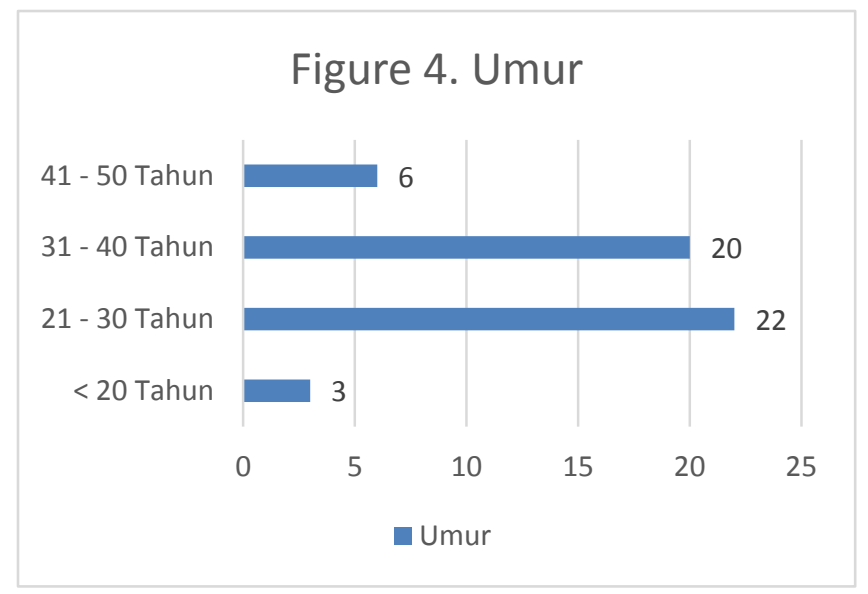

Dari Figure 4 dapat dilihat bahwa dari 51 orang responden berumur, $<20$ tahun sebanyak 3 orang 
(5,9\%), 21-30 tahun sebanyak 22 orang (43,1\%), 34 - 40 tahun sebanyak 20 orang (39,2\%) dan $41-50$ tahun sebanyak 6 orang. Hal ini memperlihatkan bahwa peserta yang mengikuti webinar lebih banyak pada umur antara 21 - 30 tahun. Dengan demikian, dapat disimpulkan bahwa yang mengikuti sosialisasi pemanfaatan digital marketing yaitu didominasi pada usia produktif.

\section{Pengalaman Menggunakan digital marketing}

Figure 5 dibawah menggambarkan pengalaman responden dalam menggunakan digital marketing sebagai berikut:

\section{Figure 5. Pengalaman menggunakan digital marketing}

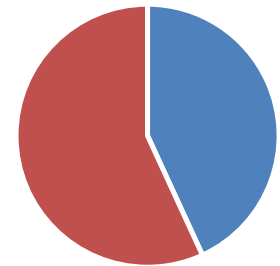

- Pernah - Belum Pernah

Berdasarkan figure 5 dapat dijelaskan bahwa 22 orang (43,1\%) pernah menggunakan digital marketing dan 29 orang $(56,9 \%)$ belum pernah menggunakan digital marketing. Hal ini menunjukkan bahwa dominan pelaku usaha di Maninjau belum mengoptimalkan digital marketing baik dalam mempromosikan dan penjualan produk. Disamping itu 28 orang $(54,9 \%)$ tidak mengetahui tujuan dan manfaat dari digital marketing.

\section{B. Analisis Deskriptif}

Berikut ini akan diuraikan analisa deskriptif jawaban responden terhadap butir pertanyaan yang diajukan.

1. Pra - Survey

Survey pra - webinar dilakukan agar dapat melihat pengetahuan, minat dan ketertarikan calon peserta dalam pemanfaatan digital marketing yang dapat dilihat pada Figure 6 sebagai berikut :

Figure 6. Hasil analisis deskriptif pra - webinar

\begin{tabular}{lllll}
\hline No & Pertanyaan / pernyataan & Mean & TCR & Ket \\
\hline 1 & Kepemahaman saudara dalam menggunakan digital marketing & 1,86 & $37,2 \%$ & Kurang \\
2 & Ketertarikan saudara dalam menggunakan digital marketing & 2,61 & $52,2 \%$ & Cukup \\
\hline
\end{tabular}

Berdasarkan Figure 6 menunjukan bahwa kepemahaman dan ketertartarikan responden terhadap digital marketing masih tergolong rendah. Hal ini memperlihatkan bahwasanya promosi yang digunakan selama ini didominasi dengan cara tradisional, tentunya akan berdampak buruk dimana pandemi COVID 19 ini memaksa wisatawan dilarang berkunjung ke daerah Maninjau yang akan mengakibatkan lemahnya 
penjualan pelaku usaha.

\section{Pasca - Survey}

Survey pasca - webinar dilakukan bertujuan untuk melihat respon peserta terhadap materi yang diberikan, kepuasan materi dan pendapat peserta tentang digital marketing yang dapat dilihat pada Figure 7 sebagai berikut:

Figure 7. Hasil analisis dekriptif pasca - webinar

\begin{tabular}{cllll}
\hline No & Pertanyaan / pernyataan & M & TCR & Ket \\
\hline 1 & Kepemahaman saudara tentang materi yang disampaikan & 3.26 & $65,2 \%$ & Baik \\
2 & Kepuasan saudara dalam penyampaian materi & 3.26 & $65,2 \%$ & Baik \\
3 & Ketertarikan saudara dalam menggunakan digital marketing & 3.86 & $77,2 \%$ & Baik \\
4 & Menurut saudara, seberapa efektifkah digital marketing dapat memperluas pasar & 3.90 & $78 \%$ & Baik \\
& penjualan? & & & \\
5 & Seberapa minat saudara untuk ikut mensosialisasikan digital marketing kepada & 3.82 & $76,4 \%$ & Baik \\
& masyarakat? & & & \\
\hline
\end{tabular}

Berdasarkan Figure 7 menjelaskan bahwa kepemahaman dan kepuasan responden terhadap materi yang disampaikan tergolong baik. Selanjutnya ketertarikan responden meningkat menjadi 77,2\% tergolong baik, hal ini memperlihatkan bahwa minat responden terhadap digital marketing meningkat jika dibandingkan dari sebelum mengikuti webinar. Selanjutnya, pendapat responden tentang keefektifan digital marketing dapat memperluas pasar penjualan pada kategori baik (78\%). Selanjutnya, minat responden untuk turut mensosialisasikan kepada masyarakat lain tergolong baik $(76,4 \%)$. Dari hasil tersebut dapat kita lihat bahwa responden antusias pada pemanfaatan teknologi yang membantu proses transaksi jual beli di masa pandemi ini. Terakhir, survey ditutup dengan meminta pendapat responden "apakah penggunaan digital marketing dapat membantu penjualan di tengah pandemi COVID 19" dan yang menjawab "iya" sebesar 44 orang $(88 \%)$.

\section{SIMPULAN DAN SARAN}

Dari webinar tersebut memperlihatkan bahwa minat responden terhadap digital marketing meningkat jika dibandingkan antara pra - survey dan pasca - survey. Selain dari pada itu, $76,4 \%$ peserta berminat untuk turut mensosialisasikan digital marketing kepada teman dan masyarakat lainnya. Beberapa masukan dari tanya jawab peserta ialah perlu adanya akomodir baik itu dari pihak akademisi dan pemerintah untuk mewadahi para pelaku usaha seperti sebuah website atau forum online yang dirancang khusus agar pemanfaatan ini berjalan optimal. Para peserta juga meminta agar adanya kesinambungan materi untuk terus diselenggarakan tentang pemanfaatan teknologi ini.

\section{UCAPAN TERIMA KASIH}

Ucapan terima kasih kami sampaikan kepada Yayasan Perguruan Tinggi Komputer Padang karena telah membiayai pengabdian ini, serta segenap jajaran Universitas Putra Indonesia "YPTK" Padang.

\section{DAFTAR PUSTAKA}

Affan, M. W., \& Irawan, D. (2020). Pkm Pendampingan Pemasaran UMKM Ikatan Pengusaha Aisyiyah Di Kota Malang. Studi Kasus Inovasi Ekonomi, 04(01), 25-31.

Busca, L., \& Bertrandias, L. (2020). A Framework for Digital Marketing Research: Investigating the Four 
Cultural Eras of Digital Marketing. Journal of Interactive Marketing, 49, 1-19. https://doi.org/10.1016/j.intmar.2019.08.002

Damarwulan, L. M., Farida, N., \& Andriyansah. (2018). The role of quality of entrepreneurial networking and responsiveness to global business environment in improving the marketing performance of indonesian exporting SMEs. Quality - Access to Success, 19(165), 91-97.

Fouskas, K., Kitsios, F., Vlachopoulou, M., \& Tsiavos, V. (2018). Challenges for Digital Expansion To International Markets. Global Fashion Management Conference, 2018(July), 370-382. https://doi.org/10.15444/gmc2018.03.08.06

Gajalakshmi. (2020). A Study On Consumer Perception Towards Digital Marketing In Vellore City Dr.C.Gajalakshmi. UGC Care Journal, 40(56), 41-47.

Kasilingam, \& Thanuja, V. (2020). Recent trends in digital marketing. UGC Care Journal, 40(03-February), 3854-3863.

Kusmulyono, M. S., \& Mulya. (2019). The Effect of Social Entrepreneurship Education on Students Ability to Social Business Opportunity Identification and Social Presence. 1(February), 123-129. https://doi.org/10.21632/ajefb

Makwana, K. (2020). Impact of Digital Marketing on Customer Buying Decision. Journal of Xidian University, 14(5), 478-490. https://doi.org/10.37896/jxu14.5/603

Rakhamtulloh, A. R., Tyas, W. P., Wahyono, H., \& Kusumo, D. I. (2019). Penggunaan Sosial Media sebagai Pemasaran Produk Umkm Berbasis Rumah Kerajinan Eceng Gondok di Klaster Klinting Ambarawa. Semnas Kolaborasi Pengabdian Kepada Masyarakat UNDIP - UNNES, 157-163.

Sedayu, M. agung, \& Suseno, S. heri. (2020). Pengembangan UMKM Berbasis Online untuk Meningkatkan Jangkauan Pemasaran di Desa Bubulak Kecamatan Bogor Barat ( Online-based MSME Development to Increase Marketing Reach in Bubulak Village , West Bogor District ). Jurnal Pusat Inovasi Masyarakat, 2(3), 402-406.

Selamat, F., Mulyawan, B., \& Tunjungsari, H. K. (2020). Peningkatan Aktivitas Pemasaran UMKM Melalui Pengembangan. Journal of Sustainable Community Development, 2(1), 17-25.

Shrestha, G. (2019). Factors Affecting Digital Marketing in Tourism An Empirical Analysis of the Nepal Tourism Sector. International Journal of Trend in Scientific Research and Development, 3(6), 169178.

Susanto, A., Sari, C. A., Moses, D. R. I., Rachmawanto, E. H., \& Mulyono, I. U. W. (2020). Implementasi Facebook Marketplace untuk Produk UMKM sebagai Upaya Peningkatan Pemasaran dan Penjualan Online. Abdimasku : Jurnal Pengabdian Masyarakat, 3(1), 42. https://doi.org/10.33633/ja.v3i1.64

Ulfah, I. F., Mustoffa, A. F., \& WIjianto, W. (2020). Strategi Pemasaran Pada Umkm Kerajinan Anyaman Plastik di Desa Karanggebang Kecamatan Jetis Kabupaten Ponorogo. DIKEMAS (Jurnal Pengabdian Kepada Masyarakat), 4(1), 26-31. https://doi.org/10.32486/jd.v4i1.430 